\title{
Normy ostrożnościowe wydawane w formie uchwal Komisji Nadzoru Finansowego wobec banków w świetle Konstytucji RP
}

\section{Wprowadzenie}

Instytucją prawną zapewniającą prawidłowe funkcjonowanie systemu bankowego, będącą jedną $\mathrm{z}$ form interwencjonizmu państwowego na rynku finansowym, jest nadzór nad rynkiem finansowym ${ }^{1}$, obejmujący także nadzór bankowy. Działania interwencyjne państwa są podejmowane ze względu na potrzebę chronienia mechanizmów rynkowych oraz reguł zachowania uczestników ryn$\mathrm{ku}^{2}$. Celem nadzoru bankowego jest więc ochrona zarówno dóbr publicznych bezpieczeństwo całego systemu finansowego ${ }^{3}$, a co za tym idzie stabilności gospodarczej państwa, jak i prywatnych - indywidualnych środków powierzanych bankom - instytucjom ,zaufania publicznego". Pomijając w tym miejscu kontrowersje związane z zakresem pojęcia „,nadzór bankowy”, jego cechami, funkcjami ${ }^{4}$, w systemie bankowym nadzór oznacza obowiązek zapewnienia przestrzegania

* Dr Edyta Rutkowska-Tomaszewska - Katedra Prawa Finansowego, Wydział Prawa, Administracji i Ekonomii, Uniwersytet Wrocławski.

${ }^{1}$ Zintegrowany nadzór nad rynkiem finansowym, sprawowany przez Komisję Nadzoru Finansowego, poza nadzorem bankowym, obejmuje nadzór: emerytalny, ubezpieczeniowy, nad rynkiem kapitałowym, nad instytucjami pieniądza elektronicznego oraz nadzór uzupełniający, sprawowany zgodnie z przepisami właściwych ustaw - art. 2 ustawy z dnia 21 lipca 2006 r. o nadzorze nad rynkiem finansowym, t.j. Dz. U. z 2012 r., poz. 1149 ze zm. (dalej: u.n.r.f.).

2 Szerzej na temat przesłanek działań interwencyjnych: R. Mroczkowski, Konstytucyjne podstawy nadzoru finansowego $w$ Polsce - dylemat pomiędzy wolnościa jednostki a bezpieczeństwem ogótu uczestników obrotu, [w:] P. J. Lewkowicz, J. Stankiewicz (red.), Konstytucyjne uwarunkowania tworzenia i stosowania prawa finansowego i podatkowego, Białystok 2010, s. 604 i n.

${ }^{3}$ Szerzej na temat bezpieczeństwa rynku finansowego m.in.: A. Jurkowska-Zeidler, Bezpieczeństwo rynku finansowego, Warszawa 2008 i powoływana tam literatura.

${ }^{4}$ Patrz szerzej na ten temat: E. Rutkowska, Nadzór bankowy w ramach nadzoru nad rynkiem finansowym, [w:] E. Fojcik-Mastalska (red.), Prawo bankowe, Wrocław 2009 i powoływana tam literatura; E. Rutkowska, Nadzór bankowy, nadzór skonsolidowany i uzupetniający, [w:] C. Kociński (red.), Nadzór administracyjny. Od prewencji do weryfikacji, Wrocław 2006, s. 226-274. 
przepisów prawa przez podmioty poddane nadzorowi. Tak rozumiany nadzór występuje, gdy między organem nadzorującym a podmiotem nadzorowanym nie ma strukturalnej zależności, a wiążący charakter środków nadzoru wynika z woli ustawodawcy, który wyposażył organ nadzoru w określone uprawnienia i nadał im wiążący charakter. Ewolucja nadzoru bankowego doprowadziła do ukształtowania pewnych form działań nadzorczych, które nie ograniczają się tylko do kontroli banków i weryfikacji ich działalności (nadzór w ścisłym znaczeniu), lecz także do prawnego wyznaczania pewnych reguł rozważnego zarządzania ryzykiem związanym z działalnością bankową (regulacje ostrożnościowe). Ustalanie takich reguł można uznać za formę nadzoru prewencyjnego, ponieważ przestrzeganie regulacji ostrożnościowych przez banki stało się ich obowiązkiem, a w razie ich naruszenia organ nadzorujący uprawniony jest do zastosowania określonych prawem środków nadzoru bankowego.

\section{Zadania i cele Komisji Nadzoru Finansowego w zakresie sprawowania nadzoru bankowego}

Zadania Komisji Nadzoru Finansowego (KNF), określone w art. 4 u.n.r.f., sformułowano $\mathrm{w}$ odniesieniu do całego rynku finansowego i mają one charakter uniwersalny - to znaczy - mogą być realizowane na poszczególnych segmentach tego rynku, w tym także na rynku bankowym. Do ustawowych zadań ogólnych KNF należy przede wszystkim sprawowanie nadzoru nad rynkiem finansowym ${ }^{5}$, w tym nadzoru bankowego.

Celem nadzoru nad rynkiem finansowym jest zapewnienie prawidłowego funkcjonowania tego rynku, jego stabilności, bezpieczeństwa oraz przejrzystości, zaufania do rynku finansowego, a także ochrona interesów uczestników tego rynku przez realizację celów określonych w ustawach regulujących nadzór nad poszczególnymi segmentami rynku finansowego ${ }^{6}$.

${ }^{5}$ Oprócz sprawowania nadzoru nad rynkiem finansowym, do zadań KNF należy także: podejmowanie działań służących prawidłowemu funkcjonowaniu rynku finansowego i mających na celu jego rozwój i konkurencyjność; podejmowanie działań edukacyjnych, informacyjnych w zakresie funkcjonowania rynku finansowego; udział w przygotowywaniu projektów aktów prawnych w zakresie nadzoru nad rynkiem finansowym; stwarzanie możliwości polubownego i pojednawczego rozstrzygania sporów między uczestnikami rynku finansowego, w szczególności sporów wynikających ze stosunków umownych między podmiotami podlegającymi nadzorowi Komisji a odbiorcami usług świadczonych przez te podmioty; wykonywanie innych zadań określonych ustawami - szerzej: E. Rutkowska-Tomaszewska, Nadzór bankowy, [w:] R. Mastalski, E. Fojcik-Mastalska, Prawo finansowe, Warszawa 2013, s. 641-662 i n.; E. Rutkowska-Tomaszewska, Nadzór nad rynkiem finansowym a nieuczciwe praktyki rynkowe banków wobec konsumentów - zakres, potrzeba i możliwości podejmowanych działań, [w:] E. Fojcik-Mastalska, E. Rutkowska-Tomaszewska (red.), Nadzór nad rynkiem finansowym. Aktualne tendencje i problemy dyskusyjne, Wrocław 2011, s. 97-112.

${ }^{6}$ E. Rutkowska, [w:] E. Fojcik-Mastalska (red.), op. cit., s. 140. 
Zważywszy na cel nadzoru bankowego wskazany w art. 133 ust. 1 p.b. ${ }^{7}$, przedmiotem nadzoru bankowego jest działalność (funkcjonowanie) banków, a nie tworzenie banku lub zakończenie jego działalności. Nieuprawnione jest zatem utożsamianie zakresu nadzoru z zakresem działania Komisji Nadzoru Finansowego. Z całokształtu przepisów prawnych odnoszących się do Komisji Nadzoru Finansowego wynika, że jest to organ, którego zakres działalności wykracza poza stricte działania nadzorcze. Komisji przypisano bowiem, oprócz tzw. nadzoru właściwego (i w jego ramach zadań ,normodawczych - wydawanie regulacji ostrożnościowych”), także zadania reglamentacyjne, zadania w zakresie sanacji banków oraz likwidacji i upadłości, zadania szczególne wobec banków hipotecznych $^{8}$. Zakres przedmiotowy nadzoru bankowego dotyczy obszarów działalności nadzorowanych banków, określonych materii - zagadnień poddanych nadzorowi.

Zgodnie z art. 133 p.b. (ust. 2 pkt 2, 5, 6, 7), określającym czynności nadzoru bankowego, nadzór: bada jakość systemu zarządzania bankiem, w szczególności systemu zarządzania ryzykiem oraz systemu kontroli wewnętrznej (w tym dostosowania do rodzaju i skali działalności banku procesu identyfikacji i monitorowania ryzyka oraz dopuszczalnego ryzyka w działalności banków); dokonuje oceny szacowania, utrzymywania i przeglądu kapitału wewnętrznego; bada przestrzeganie limitów koncentracji zaangażowań (art. 71 p.b.) i tzw. zakazu uprzywilejowania (art. 79a p.b.) oraz ocenia proces identyfikacji, monitorowania i kontroli koncentracji zaangażowań, w tym dużych zaangażowań; bada przestrzeganie przez bank, określonych przez KNF norm dopuszczalnego ryzyka w działalności banków.

Z katalogu zadań organu nadzoru bankowego (art. 4 u.n.r.f.) i czynności podejmowanych przez Komisję Nadzoru Finansowego w ramach nadzoru bankowego (art. 133 ust. 2 p.b. w związku z uchwałą nr 312/2012 KNF w sprawie trybu wykonywania nadzoru nad działalnością bankową ${ }^{9}$ ) wynika, że organ nadzorczy realizuje trzy podstawowe funkcje: licencyjną ${ }^{10}$, regulacyjną, kontrolno-administracyjną ${ }^{11}$.

${ }^{7}$ Ustawa z dnia 29 sierpnia 1997 r. Prawo bankowe, t.j. Dz. U. z 2012 r., poz. 1376 ze zm. (dalej: p.b.).

8 Szerzej na temat nadzoru nad bankami hipotecznymi: R. Bucholski, Nadzór nad działalnościa banków hipotecznych. Stan obecny i propozycje zmian, [w:] E. Fojcik-Mastalska, E. Rutkowska-Tomaszewska (red.), op. cit., s. 21-34.

${ }_{9}$ Uchwała z dnia 27 listopada 2012 r., Dz.Urz.KNF z 2012 r., poz. 20 (dalej: uchwała KNF 312/2012).

${ }^{10}$ Funkcja licencyjna polega na reglamentacji przez KNF dostępu osób i kapitału do działalności bankowej, w taki sposób, by od momentu powstania banku spełniał on warunki pozwalające na traktowanie go jako instytucji zaufania publicznego. Regulują to przepisy zawarte w ustawie Prawo bankowe, dotyczące tworzenia i organizacji banków oraz oddziałów i przedstawicielstw banków (rozdział 2 p.b.).

${ }^{11}$ Funkcja kontrolno-administracyjna KNF jest realizowana poprzez wykonywanie czynności nadzoru i stosowanie środków nadzoru, tak w stosunku do instytucji, jak też osób odpowiedzialnych za wystąpienie określonych nieprawidłowości, w określonych ustawowo przypadkach. Polega ona także na zbieraniu i analizie informacji przez nadzór bankowy, zarówno w drodze inspekcji na miejscu (w danym banku), jak i nadzoru analitycznego „zza biurka” (w siedzibie nadzoru). Istotą 
Szeroki katalog zadań KNF, wskazany w art. 4 u.n.r.f., świadczy o innych jeszcze, poza dotychczas tradycyjnie pojmowanymi, funkcjach organu nadzoru ${ }^{12}$.

Funkcja o charakterze inicjatorskim, projektodawczym i legislacyjnym ogólnie określana jako funkcja regulacyjna, której poświęcone jest niniejsze opracowanie, polega na określaniu przez KNF minimalnych standardów bezpieczeństwa w działalności banków, a więc formułowaniu przez KNF regulacji ostrożnościowych oraz nadzorowaniu ich przestrzegania przez banki.

\section{Status prawny Komisji Nadzoru Finansowego}

Komisja Nadzoru Finansowego jest organem właściwym w sprawach nadzoru nad rynkiem finansowym (art. 3 ust. 2 u.n.r.f). Nadzór nad działalnością KNF sprawuje Prezes Rady Ministrów ${ }^{13}$ (art. 3 ust. 3 u.n.r.f.), któremu KNF przedstawia coroczne sprawozdanie ze swojej działalności (art. 4 ust. 2 u.n.r.f.). Nadzór Prezesa Rady Ministrów przejawia się również w ustawowo zagwarantowanym wpływie na obsadę stanowisk kierowniczych w KNF (powoływanie i odwoływanie przewodniczącego KNF oraz jego zastępców - art. 7, art. 8 i art. 9 u.n.r.f.), na strukturę organizacyjną urzędu KNF (nadanie statutu - art. 14 u.n.r.f.) oraz sposób wynagradzania członków Komisji oraz pracowników urzędu KNF (art. 20 ust. 2 u.n.r.f.). Nadzór ten jest więc nadzorem organizacyjnym (nadawanie w drodze zarządzenia statutu Urzędu KNF) oraz nadzorem personalnym (powoływanie

tej funkcji jest identyfikowanie przez nadzór podstawowych zagrożeń w funkcjonowaniu banków, które jest prowadzone zarówno poprzez badanie nadsyłanych przez banki sprawozdań, jak i przez inspekcje przeprowadzane przez pracowników nadzoru w bankach.

${ }_{12}$ Nie można jednak utożsamiać wszystkich funkcji organu nadzoru z zakresem pojęciowym nadzoru bankowego, czy szerzej - nadzoru finansowego, ponieważ zakres zadań KNF nie pokrywa się jedynie z nadzorem bankowym. Komisja Nadzoru Finansowego posiada bowiem inne ważne zadania w celu zapewnienia prawidłowego funkcjonowania rynku finansowego i ochrony jego uczestników zwłaszcza odbiorców usług finansowych. Szerzej na ten temat: E. Rutkowska-Tomaszewska, Nadzór nad rynkiem finansowym..., s. 97-112; T. Nieborak, Działania edukacyjne i informacyjne Komisji Nadzoru Finansowego w zakresie funkcjonowania rynku finansowego jako element ksztaltowania jego stabilności, [w:] E. Fojcik-Mastalska, E. Rutkowska-Tomaszewska (red.), op. cit., s.73-79.

13 Wzbudza to kontrowersje co do niezależności KNF. Środki, które zapewniają skuteczny nadzór, nie są jednak nieograniczone i muszą wynikać bezpośrednio z przepisów prawa. Ustawa nie nadaje bowiem organowi nadzorującemu uprawnienia władczego oddziaływania. Zob. szerzej na temat kontrowersji związanych ze statusem prawnym i niezależnością KNF - A. Maślanka, I. Maj, Niezależność Komisji Nadzoru Finansowego, [w:] E. Fojcik-Mastalska, E. Rutkowska-Tomaszewska (red.), Nadzór nad rynkiem finansowym. Aktualne tendencje..., s. 63-72; uzasadnienie wyroku TK z dnia 15 czerwca 2011 r., sygn. akt K 2/09, sentencja ogłoszona 29 czerwca $2011 \mathrm{r}$. (Dz. U. Nr 134, poz. 788), uzasadnienie dostępne na stronie www.trybunal.gov.pl; Postanowienie Naczelnego Sądu Administracyjnego w Warszawie z dnia 31 sierpnia 2011 r., II GSK 1607/11, LEX nr 896392; Postanowienie Naczelnego Sądu Administracyjnego w Warszawie z dnia 31 sierpnia 2011 r., II GSK 1633/11, LEX nr 896398. 
Przewodniczącego KNF, odwoływanie Przewodniczącego KNF przed upływem kadencji w sytuacjach wskazanych w przepisie art. 8 u.n.r.f., powoływanie i odwoływanie na wniosek Przewodniczącego jego zastępców). Prezes Rady Ministrów nie ma jednak uprawnień w zakresie środków oddziaływania merytorycznego, tzn. w zakresie sprawdzania prawidłowości i legalności działania KNF (tzw. funkcji kontrolnej), np. zawieszania, uchylania lub zaskarżania decyzji. Należałoby uznać, iż przysługuje mu raczej możliwość podjęcia działań o charakterze niewładczym, takich jak: zwracanie uwagi na zaistniałe nieprawidłowości, wydawanie zaleceń, proponowanie rozwiązań, wysuwanie wniosków.

Status prawny KNF, podobnie jak niegdyś Komisji Nadzoru Bankowego ${ }^{14}$, wzbudza kontrowersje - czy należy uznać ją za centralny ${ }^{15}$ i pozaresortowy (będący poza strukturą resortów administracji) organ państwa, właściwy w sprawach nadzoru nad rynkiem finansowym, który nie będąc organem administracji rządowej, w ramach przyznanych kompetencji do wydawania postanowień i decyzji administracyjnych wykonuje w imieniu państwa zadania w sferze administracji publicznej, czy też jest organem administracji rządowej ${ }^{16}$.

Skład KNF jest siedmioosobowy: przewodniczący, dwóch zastępców oraz czterech członków, którymi są: minister właściwy do spraw instytucji finansowych albo jego przedstawiciel; minister właściwy do spraw zabezpieczenia społecznego albo jego przedstawiciel; Prezes NBP albo delegowany przez niego Wiceprezes NBP; przedstawiciel Prezydenta Rzeczypospolitej Polskiej (art. 5 ust. 2 u.n.r.f.). Przewodniczący KNF, a w razie jego nieobecności upoważniony przez niego zastępca przewodniczącego, reprezentuje Komisję oraz kieruje jej pracami (art. 13 u.n.r.f.) ${ }^{17}$.

Komisja w zakresie swojej właściwości, jako organ kolegialny podejmuje uchwały, w tej formie - w sprawach indywidualnych - wydaje decyzje administracyjne i postanowienia, określone w przepisach odrębnych (art. 11 ust. 1 u.n.r.f. ${ }^{18}$ ).

14 Od 1 stycznia 1998 r. do 31 grudnia 2007 r. organ nadzoru bankowego.

15 Zasięg terytorialny właściwości KNF obejmuje bowiem cały kraj. Komisja nie ma statusu naczelnego organu administracji publicznej i nie zajmuje zwierzchniej (nadrzędnej) pozycji względem innych organów (oraz jednostek organizacyjnych) pozostających w strukturze aparatu państwowego.

16 Niektórzy twierdzą, że fakt, iż KNF jest organem nadzorowanym przez Prezesa Rady Ministrów powoduje w istocie, że jest agendą rządową.

${ }_{17}$ Kierownictwo rozumiane jest jako najdalej posunięta możliwość ingerencji w działania organów kierowanych, większą niż nadzór czy koordynacja działań. Zob. E. Konosala, L. Zacharenko, A. Matan, Nauka administracji, Zakamycze 2000, s. 162; Z. Leoński, Nauka administracji, Warszawa 2000, s. 87 i n. Przewodniczący może bowiem skorzystać z wszelkich dostępnych środków w celu wywołania nacisku na organ kierowany.

${ }^{18}$ Uchwały podejmowane są zwykłą większością głosów, w głosowaniu jawnym, w obecności co najmniej czterech osób wchodzących w jej skład, w tym Przewodniczącego KNF lub jego zastępcy; w razie równej liczby głosów rozstrzyga głos Przewodniczącego KNF. Uchwały w imieniu Komisji podpisuje Przewodniczący Komisji, a w razie jego nieobecności upoważniony przez niego zastępca Przewodniczącego. 
Do postępowania przed KNF stosuje się przepisy Kodeksu postępowania administracyjnego ${ }^{19}$. KNF może upoważnić Przewodniczącego do podejmowania działań w jej imieniu, w tym do wydawania postanowień i decyzji administracyjnych, jednakże z wyłączeniem $\mathrm{w}$ art. 12 ust. 2 u.n.r.f. spraw, dla których właściwa jest wyłącznie KNF, które zostały uregulowane w podziale na poszczególne segmenty rynku objęte zintegrowanym nadzorem KNF.

Techniczną i merytoryczną pomoc KNF zapewnia Urząd Komisji, którego statut określający jego organizację wewnętrzną nadawany jest przez Prezesa Rady Ministrów, w drodze zarządzenia (art. 14 u.n.r.f.) ${ }^{20}$.

\section{Funkcja regulacyjna Komisji Nadzoru Finansowego w ramach nadzoru bankowego}

Istotę działalności banku, obok zarządzania przepływami strumieni pieniężnych, stanowi zarządzanie ryzykiem ${ }^{21}$, na które wystawione są gromadzone przez niego środki pieniężne ${ }^{22}$.

Ważnym elementem nadzoru bankowego jest więc działalność regulacyjna KNF, która polega na określaniu zasad działania banków, zapewniających bezpieczeństwo środków pieniężnych zgromadzonych na rachunkach bankowych (tzw. regulacje ostrożnościowe, zwane także normami ostrożnościowymi). Ich przestrzeganie bada potem organ nadzoru (art. 133 ust. 2 pkt 6 p.b.).

Podejmowane w tym zakresie przez KNF uchwały określają reguły rozważnego zarządzania ryzykiem związanym z działalnością banków i znajdują zastosowanie na poziomie gospodarki finansowej banków ${ }^{23}$. Normy ostrożnościowe,

${ }_{19}$ Ustawa z dnia 14 czerwca 1960 r. Kodeks postępowania administracyjnego (t.j. Dz. U. z 2013 r., poz. 267 ze zm.).

${ }^{20}$ Zob. Zarządzenie nr 172 Prezesa Rady Ministrów z dnia 22 listopada 2006 r. w sprawie nadania statutu Urzędowi Komisji Nadzoru Finansowego (M.P. z 2006 r. nr 84, poz. 852).

${ }^{21} \mathrm{Z}$ definicji legalnej banku (art. 2 p.b.) wynika, że podstawową cechą działalności bankowej jest wykonywanie czynności obciążających ryzykiem środki powierzone pod tytułem zwrotnym. Rodzaje ryzyka związanych z działalnością banków reguluje uchwała KNF - uchwała nr 76/2010 Komisji Nadzoru Finansowego z dnia 10 marca 2010 r. w sprawie zakresu i szczegółowych zasad wyznaczania wymogów kapitałowych z tytułu poszczególnych rodzajów ryzyka (Dz.Urz.KNF nr 2, poz. 11 ze zm.).

${ }^{22}$ Mając na uwadze powyższe, ustawa Prawo bankowe przewiduje w rozdziale 10 (art. 126130) regulacje dotyczące gospodarki finansowej oraz funduszy własnych banków - szerzej: L. Góral, [w:] M. Bączyk, E. Fojcik-Mastalska, L. Góral, J. Pisuliński, W. Pyzioł, Prawo bankowe. Komentarz, Warszawa 2007, s. 516. Przepisy te stanowią bezwzględnie obowiązujące ograniczenie zasady samofinansowania działalności banków wyrażonej w art. 129 ust. 1 p.b. i z tego punktu widzenia oznaczają ograniczenie konstytucyjnej zasady wolności gospodarczej (art. 22 Konstytucji RP).

${ }^{23}$ Szerzej na temat szczegółowej charakterystyki norm ostrożnościowych: M. Olszak, Bankowe normy ostrożnościowe, Warszawa 2011, s. 202-277. 
określające m.in. poziom i strukturę funduszy własnych, współczynnik wypłacalności, limity ryzyka walutowego czy limity koncentracji wierzytelności, wyznaczają profil i zakres dopuszczalnego ryzyka podejmowanego przez banki, przez co mają kluczowe znaczenie dla bezpiecznego funkcjonowania banku. Szczególne znaczenie ma objęcie zasadami adekwatności kapitałowej wszystkich rodzajów ryzyka.

Jednocześnie regulacje ostrożnościowe są wzorcem, według którego, w ramach bieżącego nadzoru bankowego (tzw. nadzoru właściwego), ocenia się działalność banków i na tej podstawie organ nadzoru może stosować środki weryfikacyjne i represyjne nadzoru (środki nadzorcze) ${ }^{24}$.

Ustawodawca upoważnia KNF do pewnych modyfikacji lub precyzowania niektórych regulacji ostrożnościowych ustawowych ${ }^{25} \mathrm{w}$ drodze uchwał, a także do ustanowienia innych regulacji niż są określone w ustawie.

\section{Pojęcie i zakres przedmiotowy norm ostrożnościowych}

Pojęcie norm ostrożnościowych nie ma swojej definicji legalnej, zawartej w ustawie stanowiącej źródło polskiego prawa bankowego, funkcjonującego szerzej w ramach prawa rynku finansowego ${ }^{26}$. Pojęcie norm ostrożnościowych (często używane są zamiennie pojęcia: regulacje ostrożnościowe, zasady rozważnego zarządzania ryzykiem bankowym czy też normy finansowe) nie jest rozumiane w doktrynie jednolicie; nie jest także spójna ich terminologia używana w aktach prawnych $^{27}$. Można je jednak najogólniej zdefiniować jako określone liczbowo parametry ekonomiczne, wyznaczające minimalny dopuszczalny poziom bezpieczeństwa banku, reguły mające na celu ograniczenie ryzyka w działalności banku, związanego z prowadzeniem działalności na rynku finansowym. Generalnie są to reguły postępowania mające na celu ograniczenie różnych rodzajów ryzyka związanego z prowadzeniem działalności finansowej banku i zagwarantowanie stabilności systemu finansowego, ochronę interesów podmiotów korzystających $\mathrm{z}$ usług finansowych.

${ }^{24}$ E. Rutkowska, Nadzór bankowy w ramach nadzoru nad rynkiem finansowym, [w:] E. Fojcik-Mastalska (red.), op. cit.

${ }^{25}$ Regulacje te dotyczą poziomu funduszy własnych, kapitału wewnętrznego i są umieszczone w rozdziale 10 p.b. (art. 126-130 p.b.). Przepisy stanowią bezwzględnie obowiązujące ograniczenie zasady samofinansowania działalności banków. W pewnym sensie ograniczają konstytucyjną zasadę wolności gospodarczej (art. 129 ust. 1 p.b.).

${ }^{26} \mathrm{Na}$ temat prawa rynku finansowego - jego zakresu i znaczenia - zob. C. Kosikowski, M. Olszak, Od prawa bankowego do prawa rynku finansowego, [w:] J. Głuchowski (red.), System prawa finansowego, t. IV: Prawo walutowe. Prawo dewizowe. Prawo rynku finansowego, Warszawa 2010, s. 195.

${ }^{27}$ Szerzej na temat: M. Olszak, Bankowe normy ostrożnościowe, Warszawa-Białystok 2011, s. $49 \mathrm{in}$. 
Normy ostrożnościowe dotyczą m.in.: zakresu i warunków pomniejszania funduszy banków, zakresu i szczegółowych zasad wyznaczania wymogów kapitałowych z tytułu poszczególnych rodzajów ryzyka poziomu i struktury funduszy własnych, współczynnika wypłacalności, limitów ryzyka walutowego, limitów koncentracji wierzytelności. Wyznaczają one: profil i zakres dopuszczalnego ryzyka podejmowanego przez banki, przez co mają kluczowe znaczenie dla bezpiecznego funkcjonowania banku; zakres i warunki pomniejszania funduszy banków; zakres i szczegółowe zasady wyznaczania wymogów kapitałowych z tytułu poszczególnych rodzajów ryzyka; sposób i szczegółowe zasady obliczania współczynnika wypłacalności banku; szczegółowe zasady i warunki uwzględniania zaangażowań przy ustalaniu przestrzegania limitu koncentracji zaangażowań i limitu dużych zaangażowań; szczegółowe zasady funkcjonowania systemu zarządzania ryzykiem i systemu kontroli wewnętrznej oraz szczegółowe warunki szacowania przez banki kapitału wewnętrznego i dokonywania przeglądów procesu szacowania i utrzymywania kapitału wewnętrznego.

Na podstawie art. 137 p.b. Komisja Nadzoru Finansowego: ustala w drodze uchwały ${ }^{28}$ wiążące banki normy płynności oraz inne normy dopuszczalnego ryzyka w działalności banków, szczegółowe zasady zarządzania ryzykiem związanym $\mathrm{z}$ outsourcingiem bankowym (art. 6a-6d p.b.), może wydawać rekomendacje dotyczące dobrych praktyk ostrożnego i stabilnego zarządzania bankami. Komisja Nadzoru Finansowego określiła w drodze uchwały (art. 128 ust. 6 p.b.) dodatkowe pozycje bilansu banku oraz zakres, sposób i warunki ich wyznaczania, szczegółowe warunki szacowania kapitału wewnętrznego i dokonywania przez bank przeglądów, zakres i szczegółowe zasady wyznaczania wymogów kapitałowych, w tym zakres i warunki stosowania metod ${ }^{29}$.

${ }^{28}$ W tym zakresie na podstawie art. 137 p.b. zostały wydane przez KNF m.in. uchwały: uchwała $\mathrm{z}$ dnia 8 listopada $2000 \mathrm{r}$. w sprawie ustalenia normy dopuszczalnego ryzyka walutowego w działalności banków (Dz. Urz. NBP z 2000 r. nr 15, poz. 27 ze zm.); uchwała nr 386/2008 KNF z dnia 17 grudnia 2008 r. w sprawie ustalenia wiążących banki norm płynności Dz.Urz.KNF.2008.8.40 ze zm.); uchwała nr 151/2011 KNF z dnia 7 czerwca 2011 r. w sprawie wydania Rekomendacji R dotyczącej zasad identyfikacji bilansowych ekspozycji kredytowych, które utraciły wartość, wyznaczania odpisów aktualizujących z tytułu utraty wartości bilansowych ekspozycji kredytowych oraz rezerw na pozabilansowe ekspozycje kredytowe (Dz.Urz.KNF.2011.6.17); uchwała nr 18/2011 KNF z dnia 25 stycznia 2011 r. w sprawie wydania Rekomendacji S dotyczącej dobrych praktyk w zakresie ekspozycji kredytowych zabezpieczonych hipotecznie (Dz.Urz.KNF.2011.3.6); uchwała nr 134/2010 KNF z dnia 5 maja 2010 r. w sprawie wydania Rekomendacji A dotyczącej zarządzania ryzykiem towarzyszącym zawieraniu przez banki transakcji na rynku instrumentów pochodnych Dz.Urz.KNF.2010.3.20; uchwała nr 52/2010 KNF z dnia 23 lutego 2010 r. w sprawie wydania Rekomendacji T dotyczącej dobrych praktyk w zakresie zarządzania ryzykiem detalicznych ekspozycji kredytowych (Dz.Urz.KNF.2010.2.12); uchwała nr 389/2008 KNF z dnia 17 grudnia 2008 r. w sprawie wykazu dokumentów załączanych do wniosków do KNF w sprawach o wydanie zezwolenia na utworzenie banku, o wyrażenie zgody na powołanie członków zarządu banku oraz do informacji o składzie zarządu przedstawianej KNF przez radę nadzorczą banku (Dz.Urz.KNF.2008.8.43 ze zm.).

${ }^{29}$ Uchwała nr 76/2010 Komisji Nadzoru Finansowego z dnia 10 marca 2010 r. w sprawie zakresu i szczegółowych zasad wyznaczania wymogów kapitałowych z tytułu poszczególnych rodzajów ryzyka (Dz.Urz.KNF nr 2, poz. 11 ze zm.). 


\section{Charakter prawny uchwał Komisji Nadzoru Finansowego w zakresie norm ostrożnościowych}

Ustawodawca, upoważniając KNF do ustalania w formie uchwał wiążących banki norm płynności i innych norm dopuszczalnego ryzyka w działalności banków (art. 137 pkt 3 p.b., art. 128 p.b.), nie określił charakteru prawnego wydawanych przez nią aktów.

Uchwały te zawierają normy mające charakter powszechnie obowiązujący i są adresowane do jednostek organizacyjnych prawnie samodzielnych, posiadających osobowość prawną i samodzielnie prowadzących gospodarkę finansową. Pomiędzy KNF a bankami nie zachodzą żadne więzy „organizacyjnej podległości". W związku z tym przepisy ustawowe, które zawierają upoważnienia dla KNF do wydawania aktów posiadających walor „powszechnego obowiązywania”, sprzeczne są $\mathrm{z}$ art. 87 ust. 1 Konstytucji ${ }^{30}$ ustanawiającym zamknięty system źródeł prawa powszechnie obowiązującego, biorąc pod uwagę zamknięty katalog źródeł powszechnie obowiązującego prawa, o czym przesądza art. 87 Konstytucji RP, a także fakt, iż akty prawa wewnętrznego, o których stanowi art. 93 Konstytucji RP, mogą zawierać jedynie normy wewnętrznie obowiązujące jednostki organizacyjne podległe organowi stanowiącemu te akty ${ }^{31}$.

$\mathrm{Z}$ uwagi na powyższe, rodzi się pytanie o charakter prawny aktów podustawowych KNF, kierowanych do określonych typów instytucji finansowych, w tym banków. Mimo iż w świetle Konstytucji RP akty podustawowe organu nadzoru (uchwały i zarządzenia) adresowane do instytucji finansowych raczej nie powinny być traktowane jako akty kierownictwa wewnętrznego, ponieważ nie są wydawane w stosunku do podmiotów podległych służbowo lub organizacyjnie, przekonujące wydaje się wyrażone w doktrynie i orzecznictwie stanowisko, że ze względów funkcjonalnych należy je kwalifikować jako akty prawa wewnętrznego ${ }^{32}$.

${ }^{30}$ Konstytucja Rzeczpospolitej Polskiej z dnia 2 kwietnia 1997 r., Dz. U. Nr 78, poz. 483 (dalej: Konstytucja).

${ }^{31}$ Charakter aktów prawa wewnętrznego mają uchwały Rady Ministrów, zarządzenia Prezesa Rady Ministrów i ministrów oraz zarządzenia Prezydenta RP (art. 93 ust. 1 i art. 142 ust. 1 Konstytucji RP).

32 Pogląd powyższy w odniesieniu do zarządzeń Prezesa NBP, uchwał Zarządu NBP, uchwał Rady Polityki Pieniężnej oraz uchwał KNF wyraża E. Fojcik-Mastalska, [w:] E. Fojcik-Mastalska (red.), Prawo bankowe, Wrocław 2009, s. 20. Szerzej autorka omawia problematykę podstawowych aktów prawa w: Podustawowe źródła prawa bankowego, „Prawo Bankowe” 2002, nr 4, s. 41 i n. Względy funkcjonalne zdają się przemawiać także za przyznaniem powszechnie obowiązującej mocy przynajmniej niektórym uchwałom Rady Polityki Pieniężnej (np. uchwałom w sprawie założeń polityki pieniężnej państwa) i niektórym zarządzeniom Prezesa NBP (np. zarządzeniom o emisji nowych banknotów i monet). Zob. R. Tupin, Akty normatywne organów Narodowego Banku Polskiego oraz organów nadzoru nad rynkiem finansowym w świetle postanowień Konstytucji $R P$, [w:] C. Kosikowski (red.), Zasady ustroju społecznego i gospodarczego w procesie stosowania Konstytucji, Warszawa 2006, s. 200 i n. Por. wyrok TK z dnia 28.06.2000 r., K 25/99 (Dz. U. Nr 53, poz. 648) z komentarzem E. Fojcik-Mastalskiej w „Prawie Bankowym” 2000, nr 7-8, s. 13. Sąd Najwyższy uznał legalność uchwał KNB jako aktów prawa wewnętrznego w postanowieniu Sądu Najwyższego z dnia 7 grudnia 1999 r., I CKN 796/99, OSNC 2000, nr 6, poz. 114. 
Ponadto, nawet jeżeliby przyjąć, że stanowią one - aczkolwiek ułomne, bo uzasadnione jedynie funkcjonalną podległością instytucji finansowych Komisji - tzw. prawo wewnętrzne (wewnątrzsystemowe), nie można w żadnym wypadku uznać je za wiążące również wobec klientów tych instytucji (osób trzecich) ${ }^{33}$.

Komisja nie jest organem konstytucyjnie uprawnionym do wydawania przepisów powszechnie obowiązujących i, jak się wydaje, w obecnym stanie prawnym, w sposób nieuzasadniony została upoważniona do ich wydawania. Uchwały KNF nie są też aktami kierownictwa wewnętrznego, choć ustawa wskazuje na ich wiążący charakter (art. 137 p.b.) Mają więc moc prawną taką jak zalecenia (brak podległości organizacyjnej), ale jednak w rzeczywistości są dla banku wiążące; zignorowanie zaleceń przez bank może skutkować zastosowaniem przez KNF środków nadzorczych wymienionych w art. 138 ust. 3 p.b. (zarówno ad rem, jak $\mathrm{i}$ ad personam).

Jest to problem podustawowych aktów, innych od rozporządzeń, w formie uchwał czy zarządzeń, które, w myśl konstytucyjnych regulacji dotyczących źródeł prawa, nadają im charakter aktów prawa wewnętrznego, jeżeli skierowane są do podmiotów podporządkowanych organizacyjnie organom wydającym te akty. W systemie bankowym takie podporządkowanie nie występuje, banki nie podlegają organizacyjnie KNF. Generuje to problem wątpliwości co do mocy obowiązującej wobec banków takich aktów. Jeśli przyjąć, że stanowią one ułomne, bo uzasadnione funkcjonalną podległością banków tym organom - tzw. prawo wewnętrzne (wewnątrzsystemowe), nie można uznać ich za wiążące wobec klientów banku. Trudno uznać, bez dodatkowych zastrzeżeń, ich mocy wiążącej wobec banków, uzasadnianej podległością funkcjonalną ${ }^{34}$. Wprawdzie w wyniku ostatnich zmian ustawy Prawo bankowe ograniczono liczbę upoważnień prawotwórczych do wydawania aktów podustawowych w formie uchwał, jednak nadal istnieją one w sprawach nadzoru bankowego, co wzbudza, ciągle nierozwiązaną, kwestię ich niekonstytucyjności. Uchwały te zawierają treści niezwykle istotne dla banków, są to akty faktycznie respektowane przez banki (wymusza to „siła perswazji") ze strony upoważnionych ustawowo do ich wydawania organów ${ }^{35}$.

\section{Podsumowanie}

Jest oczywiste, że kontrowersyjnych regulacji ostrożnościowych w postaci uchwał KNF, na gruncie zamkniętego systemu źródeł prawa powszechnie obowiązującego, nie można obecnie, bez dodatkowych zastrzeżeń, zaliczyć do norm

${ }^{33}$ E. Fojcik-Mastalska, [w:] E. Fojcik-Mastalska (red.), op. cit., s. 20.

${ }^{34}$ Dał temu wyraz TK w wyroku z dnia 28 czerwca 2000 r., sygn. akt K 25/99 (Dz. U. Nr 53, poz. 648), w którym zastosowano taki punkt widzenia, ale tylko w odniesieniu do konstytucyjnie wyrażonych, wyłącznych kompetencji NBP w dziedzinie polityki pieniężnej.

${ }^{35}$ E. Fojcik-Mastalska [w:] E. Fojcik-Mastalska (red.), op. cit., s. 20. 
prawa powszechnie obowiązującego. Komisja Nadzoru Finansowego nie jest także organem konstytucyjnie wyposażonym w uprawnienia prawotwórcze. Z uwagi na to, w aktualnym stanie prawnym wydaje się, że należą one do zróżnicowanej kategorii przepisów mających charakter wewnętrznych aktów normatywnych w rozumieniu art. 93 Konstytucji. Na gruncie art. 93 Konstytucji przyjmuje się, że system aktów prawa wewnętrznego ma - w zakresie podmiotowym - charakter systemu otwartego. Przepis ten określa cechy wewnętrznych aktów normatywnych przez wskazanie, że mogą być one wydawane na podstawie ustawy, podlegają kontroli co do ich zgodności z powszechnie obowiązującym prawem, obowiązują tylko jednostki organizacyjne podległe organowi wydającemu te akty i nie mogą stanowić podstawy decyzji organów państwowych wobec obywateli i osób prawnych oraz innych podmiotów.

Ustawowo zagwarantowane kompetencje nadzorcze Komisji Nadzoru Finansowego i szerokie powiązania między tym organem a bankami komercyjnymi pozwalają na przesądzenie o podległości funkcjonalnej w omawianym zakresie banków będących adresatami aktów wewnętrznych oraz zaliczenie tych uchwał do kategorii aktów prawa wewnętrznego. Komisja Nadzoru Finansowego, będąc podmiotem uprawnionym i zobowiązanym do realizacji - w interesie publicznym - zadań z zakresu nadzoru bankowego oraz zapewnienia bezpieczeństwa sytemu bankowego, wskazanych w ustawie Prawo bankowe, została wyposażona - także przez ustawę - w odpowiedni instrument prawny służący do realizacji tych zadań.

Podkreślić należy, że bez funkcji regulacyjnej KNF nie byłoby możliwe prawidłowe i efektywne sprawowanie nadzoru nad rynkiem bankowym i zapewnienie jego bezpieczeństwa, choć problematyczną, z punktu widzenia zgodności z Konstytucją, pozostaje nadal nierozwiązana kwestia uchwał KNF powszechnie obowiązujących, zawierających normy abstrakcyjne i ogólne w zakresie norm dopuszczalnego ryzyka w działalności banków. Jak się wydaje, z uwagi na specyfikę działalności banków, potrzebę natychmiastowej niemalże reakcji na stwierdzone nieprawidłowości oraz konieczność zapewnienia bezpieczeństwa rynku finansowego podmiotem właściwym do wydawania norm ostrożnościowych, z uwagi także na długotrwałość ,procesu legislacyjnego”, nie wydaje się minister właściwy do spraw instytucji finansowych - minister finansów. Z praktyki znane są przypadki inicjowania przez KNF potrzeby wydania lub zmiany aktów prawnych regulujących funkcjonowanie rynku finansowego, wynikające w dużej mierze z informacji docierających do KNF z samego rynku, które wymagają także podejmowania szybkich działań regulacyjnych. Tymczasem wiele z tych inicjatyw nie doczekało się, lub z dużym opóźnieniem, dalszych etapów. Warto jednak w tym miejscu zaznaczyć, że KNF nie przysługuje prawo inicjatywy ustawodawczej, choć należałoby taką ewentualność rozważyć, przewidując jednocześnie ,specjalny" jej tryb, z uwagi na konieczność szybkiego reagowania na sytuację na rynku finansowym. 
Szczególnie istotne w sytuacjach kryzysowych na rynku finansowym jest to, by nadzór był sprawowany efektywnie w celu zapewnienia bezpieczeństwa tego rynku, a to wymaga podejmowania ,szybkich decyzji”. W tym stanie rzeczy, uwzględniając aktualny stan prawny, KNF wydaje się najbardziej właściwym organem do wydawania takich aktów, bowiem nie jest możliwe skuteczne sprawowanie nadzoru i wypełnianie jego podstawowego celu, jakim jest zapewnienie bezpieczeństwa systemu bankowego, tym samym bezpieczeństwa środków przechowywanych na rachunkach bankowych, bez możliwości wydawania norm ostrożnościowych i badania ich przestrzegania przez organ nadzoru. Nie wyklucza to jednak w przyszłości konieczności uporządkowania tej kwestii poprzez zmianę Konstytucji i uwzględnienie tej nietypowej, szczególnej sytuacji, w której organ nadzoru wydaje akty wykonawcze do ustaw zawierające normy powszechnie obowiązujące.

Sytuacja wydaje się patowa, a problem niekonstytucyjności takich aktów nadal pozostaje nierozwiązany i na stan dzisiejszy nierozwiązywalny. Poza ewentualną zmianą Konstytucji żadna koncepcja nie wydaje się w pełni słuszna, poprawna i przydatna do rozwiązania tego problemu. 